\title{
ECOLOGICAL STUDIES ON PARLATORIA ZIZIPHI (LUCAS) INFESTING NAVEL ORANGE TREES IN MENOUFIA GOVERNORATE, EGYPT
}

\author{
H.A. Nabil(1), B.M. Eldefrawy(2), A.A.A. El- Dash(2) and Safaa H. Elhendawy(1) \\ 1- Plant Protection Research Institute, Agricultural Research Centre \\ 2- Econ. Entom. \&Agric. Zoo. Dept., Faculty of Agric., Menoufia University
}

Received: Oct. 28,2018

Accepted: Oct. 31,2018

\begin{abstract}
Ecological studies were carried out on the Parlatoria black scale, Parlatoria ziziphi (Lucas) (Hemiptera: Diaspididae) and its associated parasitoid on navel orange trees at Faculty of Agriculture farm in Shebin El-Kom, Menoufia Governorate, Egypt during two successive years from June 2015 until May 2017. The seasonal abundance and activity periods of different stages of $P$. ziziphi and its associated parasitoid on navel orange trees and the effects of some weather factors on both insect and parasitoid were considered. The obtained results revealed that the total numbers of alive stages had two peaks of activity during the first year (2015-2016) they took place at September and January. While, during the second year (2016-2017) the total number of alive stages showed one peak of activity there was in September. Aphytis sp. (Hymenoptera: Aphelinidae) was recorded as a parasitoid of P. ziziphi which appeared two peaks of parasitism during the first year (2015-2016) in November and May. While, during the second year one peak was occurred in November. The total effects of some weather factors (Temp. ${ }^{\circ} \mathrm{C}, \mathrm{RH} \%$ and solar radiation) in this study on the total numbers of alive stages of $P$. ziziphi during the two successive years were 89.47 and $85.30 \%$, successively. The obtained results revealed that $P$. ziziphi had two to three annual generations on navel orange trees, the generation durations were varied from three to five months.
\end{abstract}

Key words: Ecology, Parlatoria ziziphi, Parlatoria black scale, navel orange, Aphytis sp.

\section{INTRODUCTION}

In Egypt, navel orange, Citrus sinensis (L.) is represented one of the most economically crops. A great attention has been done to increase the production and improve the quality and quantity of this crop. Now, the policy strategy of Egypt is to increase the quality level of exported crops to certain European countries.

Scale insects have been reported as serious pests attacking a huge number of host plants around the world (Miller et al. 2002; Miller 2005; Germain 2008; Kondo et al. 2008; Franco et al. 2009; Pellizzari \& Germain 2010 and Mazzeo et al. 2014). These insects are found on various parts of their hosts, and may infest leaves, twigs, branches and roots, and some live inside plant domatia. However, some species feed on the parenchyma tissue by directly feeding on the contents of parenchyma cells (Kondo et al. 2008). They feed almost exclusively on the phloem of their host plants to which they cause direct damage, but they can also cause indirect damage by transmitting plant pathogens through injection or through the build-up of honeydew, promoting the attack of plant pathogens (Ross et al. 2010).

The Parlatoria black scale, Parlatoria ziziphi (Lucas) was discovered infesting citrus in southern Florida in 1985. It is considered a major pest in countries bordering the Mediterranean, Tropical 
Asia, Parts of South America, and the Caribbean. Scales infest leaves, twigs, and fruits and because they adhere so strongly, cause rejection of fresh fruit in markets. Large populations cause chlorosis and early drop of leaves, dieback of twigs and branches, and distortion of fruit. The scale had 2 to 3 generations per year (Helmy, 2000; Capinera, 2008; Tawfeek and Abu-Shall, 2010 and Hassan et al., 2012).

Therefore, the present investigation was planned to study:

1. Seasonal abundance and activity periods of different stages the Parlatoria black scale, $P$. ziziphi (Lucas) on navel orange.

2. The associated parasitoid as well as their role as biological control agents in reducing the infestation by the insect pest.

3. Evaluate the effects of some weather factors on the insect pest and its associated parasitoids.

4. Studying the number of the insect generations and their durations on navel orange trees under field conditions.

\section{MATERIALS AND METHODS}

Field experiments were carried out in citrus horticulture, Faculty of Agriculture in Shebin El-Kom, Menoufia Governorate. The study was continued for two successive years, from June 2015 until May 2017. The farm received normal agricultural practices and no chemical control was applied.

\section{Population densities and seasonal abundance}

The study was started from June 2015 until May 2017, in an area of about one feddan of navel orange, Citrus sinensis (L.). Five trees of were selected and labeled. These trees were nearly similar in size, age and vegetation. Each tree was divided into four main directions (East, West, North and South).

For sampling, five leaves were picked up at random twice a month from each direction, i.e. 100 leaves per sample (5 trees $\times 4$ directions $\times 5$ leaves). The samples were put in polyethylene bags and transferred into the laboratory for carefully inspection. These samples were examined in the same day by the aid of stereomicroscope. The stages of scale insects and their associated natural parasitoids were counted and recorded.

These samples were examined in the same day by the aid of stereomicroscope. The stages of scale insects and their associated natural parasitoids were counted and recorded. The annual generations of scale insects were determined according to Audemard and Milaire (1975) and emended by Jacob (1977).

\section{Estimation of parasitism ratios}

To study the parasitism ratios of scale insects the previously collected samples for surveying studies were carefully inspected and sorted. Then, samples were separated into healthy alive insects and parasitized ones which appearing emerging holes of adult parasitoids or including parasitoid immature stages (larvae or pupae). Each healthy alive insect and parasitized ones were counted and recorded. Parasitized insects were preserved in glass jars covered with muslin cloth by the aid of rubber bands and kept under laboratory conditions until parasitoids emergence. Percentage of total parasitism for each sample was estimated. All emerging parasitoids were mounted in canada balsam and photomagnified under stereomicroscope camera. Parasitoid was identified with helping of Prof. Dr. S. Abd-Rabou, Chief Researcher, Scale Insects and Mealybugs Department, Plant Protection 
Research Institute, Agricultural Research Center, Egypt.

\section{Effect of climatic factors on the insect population and parasitism ratios}

The prevailing means of air temperature $\left({ }^{\circ} \mathrm{C}\right)$, relative humidity $(\mathrm{RH} \%)$ and solar radiation $\left(\mathrm{MJ} / \mathrm{m}^{2}\right)$ in the experimental area during the periods of the present study were obtained from the Central Laboratory for Agricultural Meteorology, Agricultural Research Center, Ministry of Agriculture. The relationships between climatic factors and each of population densities of predominant scale insects, parasitism ratios and total insect populations were studied. Simple correlation, partial regression values and explained variance (E.v\%) were calculated using COSTAT Computer Program (2005).

\section{RESULTS AND DISCUSSION}

Seasonal abundance of The Parlatoria black scale, Parlatoria ziziphi (Lucas) on navel orange trees

\section{Females population}

Data in Tables (1 and 2) showed that the females population had two peaks of females activity in the first and second years (2015-2016 and 2016-2017) there were in September (283 females/ 200 leaves) and in January (733 females) during the first year. While, during the second year females activity recorded two peaks of activity in September (956 females) and in November (838 females).

Generally, the total number of females during the second year (5326 females) was obviously higher as compared with that recorded during the first one (4043 females).

\section{Males population}

Data presented in Tables (1 and 2) showed that the males population had three peaks of activity during the first years (2015-2016) there were in September (23 males), November (48 males) and March (67 males). While, during the second year (2016-2017) males population showed one peak of activity there was in October with value of (65 males).

In general, the male population during the first year (424 males) was obviously higher in comparison with that recorded during the second one (416 males).

\section{Nymphs population}

Data given in Tables (1 and 2) showed the nymphs population had five peaks of activity during the first year (2015-2016) there were in July, October, December, February and April with values of $(16,15$, 156, 56, 52 nymphs), respectively. While, during the second year (2016-2017) nymphs population showed two peaks of activity there were in September (361 nymphs) and in February (33 nymphs).

Generally, the total number of nymphs population during the second year was clearly higher than that recorded during the first one with counts of 1015 and 441 nymphs, successively.

\section{Total number of alive stages}

As shown from obtained data in Tables (1 and 2) the total number of alive stages showed two peaks of activity during the first year (2015-2016) they took place at September (316 individuals) and January (819 individuals). While, during the second year (2016-2017) the total number of alive stages showed one peak of activity there was in September (1374 individuals).

In general, the population of total alive stages during the second year (6757 individuals) was obviously higher in comparison with that recorded during the first one (4908 individuals). 
H.A. Nabil, et al.,

\begin{tabular}{|c|c|c|c|c|c|c|c|c|c|c|c|c|c|c|c|c|}
\hline 蒙 & \multicolumn{2}{|c|}{ 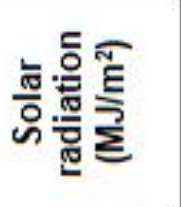 } & $\stackrel{n}{\mathscr{2}}$ & ָ̃ & 웅 & $\stackrel{\square}{=}$ & 요 & $\underset{\infty}{\sim}$ & $\stackrel{\infty}{\omega}$ & $\stackrel{N}{N}$ & ? & $\stackrel{m}{\stackrel{m}{m}}$ & $\stackrel{n}{\digamma}$ & $\underset{\sigma}{\sigma}$ & & \\
\hline  & \multicolumn{2}{|c|}{ 좀 $\bar{g}$} & ㄱ. & กิ & 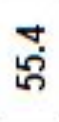 & กิ่ & $\overline{8}$ & $\underset{N}{N}$ & $\underset{\sim}{\mathbb{N}}$ & تே & ปี่ & ثิं & $\stackrel{\circ}{\frac{1}{8}}$ & $\stackrel{\circ}{\dot{y}}$ & & \\
\hline 戛 & \multicolumn{2}{|c|}{ 远 } & חి & ¿্ं & $\frac{\sigma}{\dot{m}}$ & $\stackrel{\infty}{\stackrel{一}{~}}$ & ฝี & 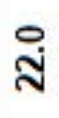 & $\stackrel{\circ}{\check{1}}$ & $\stackrel{\circ}{\circ}$ & 함 & 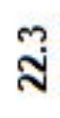 & $\stackrel{\sim}{\sim}$ & $\stackrel{m}{\sim}$ & & \\
\hline \multirow{8}{*}{ 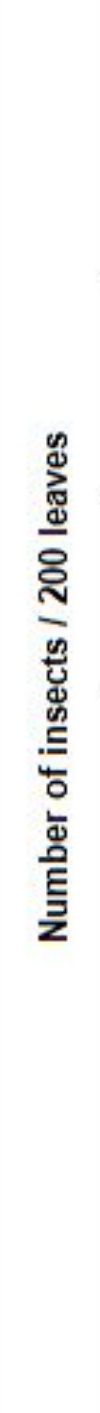 } & $\frac{n}{\frac{n}{0}}$ & 。 & 훌 & $\stackrel{\bullet}{\stackrel{f}{r}}$ & $\underset{+}{\stackrel{Y}{*}}$ & $\stackrel{m}{\sim}$ & $\stackrel{\infty}{\dot{q}}$ & 尽 & $\underset{\nabla}{F}$ & శ్లి & 옹 & $\begin{array}{l}\hat{\sigma} \\
\stackrel{\circ}{\circ}\end{array}$ & $\begin{array}{l}\bar{n} \\
6\end{array}$ & $\frac{\oplus}{\sigma}$ & & $\begin{array}{l}\stackrel{2}{\circ} \\
\text { के }\end{array}$ \\
\hline & స్ & $\dot{0}$ & 6 & $m$ & $\nabla$ & $=$ & $=$ & $\mathscr{q}$ & 요 & $\overline{0}$ & $\underset{ }{ }$ & $\stackrel{n}{2}$ & $\stackrel{\llcorner}{2}$ & 织 & $\bar{\kappa}$ & \\
\hline & \multicolumn{2}{|c|}{$\begin{array}{l}\frac{2}{\frac{2}{5}} \\
\frac{5}{2}\end{array}$} & $\begin{array}{l}\text { ஜூ } \\
\text { กี }\end{array}$ & $\begin{array}{l}\text { ̊̊ } \\
\text { ڤి }\end{array}$ & లి & $\frac{\text { m }}{m}$ & 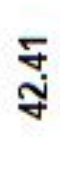 & กี & $\begin{array}{l}\text { ळ̊ } \\
\text { బై }\end{array}$ & $\begin{array}{l}\stackrel{y}{0} \\
\text { ले }\end{array}$ & 号 & 占 & $\begin{array}{l}\text { ஓ } \\
\text { ঙ্ }\end{array}$ & $\begin{array}{l}\text { S̆ } \\
\text { ஸें }\end{array}$ & & $\begin{array}{l}\text { ने } \\
\text { ळ్ }\end{array}$ \\
\hline & \multicolumn{2}{|c|}{ 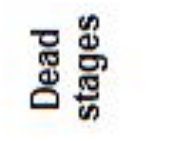 } & $\approx$ & $\approx$ & Y & 5 & $\stackrel{\infty}{\underset{\sim}{+}}$ & 尽 & $\stackrel{\sim}{\approx}$ & ฯి & है & 8 & $\frac{m}{8}$ & $\stackrel{\circ}{\circ}$ & ले & \\
\hline & \multirow{4}{*}{ 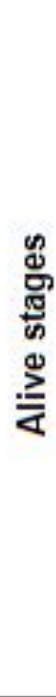 } & 퐁 & ๓ి & $q$ & เి & $\stackrel{\oplus}{m}$ & ర్ & 오 & $\stackrel{\infty}{\infty}$ & $\frac{\sigma}{\infty}$ & ஜ & $\underset{6}{\mathbb{6}}$ & กี & $\stackrel{\infty}{\infty}$ & ᄋ̊ & \\
\hline & & हू & 으 & $\dddot{2}$ & $\sigma$ & 으 & $\stackrel{n}{2}$ & 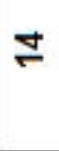 & $\stackrel{6}{5}$ & ๗ี & เึ & $\stackrel{\infty}{m}$ & กี & Y & $\overline{8}$ & \\
\hline & & $\frac{g}{\stackrel{g}{\text { d }}}$ & $\omega$ & 으 & サ & ๗ & $\bar{v}$ & $\stackrel{\infty}{q}$ & $\stackrel{5}{8}$ & 3 & छ & $\sqrt{6}$ & q & $\approx$ & ป & \\
\hline & & 造 & क & 유 & กิ & జ్ & 6 & $\stackrel{\infty}{\text { m }}$ & $\mathscr{~}$ & & తి & ํํ & 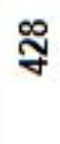 & 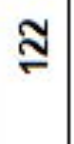 & ণ্ & \\
\hline & \multicolumn{2}{|c|}{ 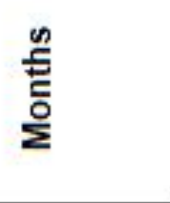 } & த் & $\overline{5}$ & 宩 & ஸें & t્ర & 을 & هُ & $\begin{array}{l}\stackrel{0}{\circ} \\
\dot{\bar{\pi}} \\
\end{array}$ & Фं & $\stackrel{\text { कूँ }}{\Sigma}$ & 远 & $\mathbb{\pi}^{\mathrm{a}}$ & $\begin{array}{l}\text { 푕 } \\
\text { 음 }\end{array}$ & 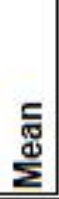 \\
\hline
\end{tabular}




\begin{tabular}{|c|c|c|c|c|c|c|c|c|c|c|c|c|c|c|c|c|}
\hline \multirow{3}{*}{ 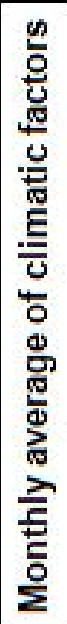 } & \multicolumn{2}{|c|}{ 능을 } & ஜ̊̊ & $\stackrel{m}{\tilde{\sigma}}$ & E. & $\stackrel{\circ}{\check{\sigma}}$ & $\stackrel{\infty}{\circ}$ & 웅 & 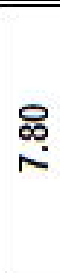 & ○్ & $\stackrel{\infty}{\circ}$ & 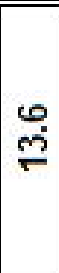 & மூ & $\stackrel{m}{\infty}$ & & \\
\hline & \multicolumn{2}{|c|}{ 폼 } & $\frac{n}{8}$ & 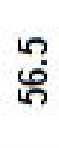 & ก) & مُ & வั & ரீ. & हิ & ָู & ชె & مึ & $\frac{0}{5}$ & r. & & \\
\hline & \multicolumn{2}{|c|}{ 远 す } & న్ & $\stackrel{\infty}{\infty}$ & ำ & ஜू & ஜ & ֶ̊ & ர் & $\stackrel{+}{\infty}$ & $\stackrel{0}{\grave{N}}$ & 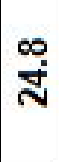 & $\stackrel{\circ}{\stackrel{\circ}{\sim}}$ & $\stackrel{n}{\sim}$ & & \\
\hline \multirow{8}{*}{  } & \multirow{2}{*}{$\begin{array}{l}\frac{n}{0} \\
\frac{0}{0} \\
\frac{9}{00} \\
\frac{\pi}{05} \\
0\end{array}$} & ஃீ & हृ & ్ㅜ & ஓ̊ & 옹 & 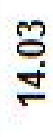 & స̊ํ․ & $\begin{array}{l}\text { के } \\
\text { कृ }\end{array}$ & 움 & స్ & รู & జ̊ & $\begin{array}{l}\mathscr{~} \\
\text { ษ్ }\end{array}$ & & $\begin{array}{l}\hat{\sigma} \\
\infty \\
\infty\end{array}$ \\
\hline & & $\dot{0}$ & $\nabla$ & in & হ & 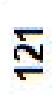 & సิ & $\stackrel{0}{*}$ & क్ & 品 & लె & $\tilde{ల}$ & 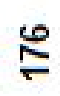 & $\stackrel{\circ}{\circ}$ & స్రి & \\
\hline & \multicolumn{2}{|c|}{ ¿ } & ले & ரீ: & ڤ్ & 守 & $\begin{array}{l}\widehat{0} \\
\text { هి }\end{array}$ & है & กิ & छొ & 仓̊ & 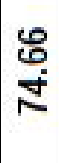 & $\begin{array}{l}\text { \% } \\
\text { ᄋं }\end{array}$ & 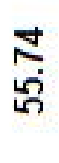 & & 옹 \\
\hline & \multicolumn{2}{|c|}{ 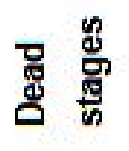 } & $\bar{v}$ & 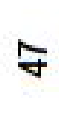 & ำ & 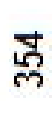 & ஜ̊ & ஜ्ల & 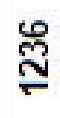 & ్ㅇㅇ & হ్ & జ̊ & 웡 & $\stackrel{m}{\circ}$ & స్ & \\
\hline & \multirow{4}{*}{ 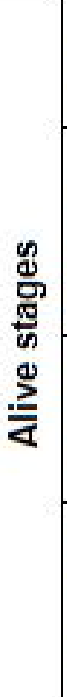 } & 퐁 & f & 운 & 羿 & $\underset{m}{\stackrel{N}{m}}$ & $\frac{5}{E}$ & ஜृ & $\sqrt{n}$ & ஜํํ & 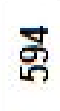 & $\frac{n}{m}$ & $\cong$ & 함 & $\frac{5}{6}$ & \\
\hline & & $\frac{n}{\sum_{z}^{n}}$ & 士 & ్ㅏ & ๒ే & $\bar{\varnothing}$ & సี & 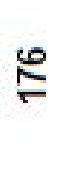 & นึ & $\bar{N}$ & ल & 士 & $r$ & $\omega$ & 용 & \\
\hline & & $\frac{\mathscr{g}}{\frac{d}{g}}$ & $N$ & $\bar{v}$ & I & 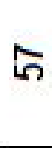 & 6 & กี & 苛 & $\mathcal{Y}$ & $\bar{m}$ & 요 & $\rightleftarrows$ & $\forall$ & $\frac{6}{8}$ & \\
\hline & & 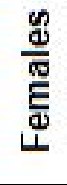 & $\stackrel{\sigma}{\Gamma}$ & $\stackrel{9}{5}$ & ભె & ڤొ & స్心 & $\stackrel{\infty}{\infty}$ & ్ํ & กิ & గొగ & $\bar{\Sigma}$ & 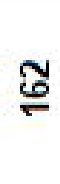 & ஓे & గ్గె & \\
\hline \multicolumn{3}{|c|}{$\stackrel{n}{E}^{n}$} & Б & $\rightrightarrows$ & 光 & $\stackrel{\Phi}{\oplus}$ & பூ & 울 & هั & 충 & Фें & 产 & 高 & $\sum^{\frac{\pi}{2}}$ & 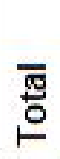 &  \\
\hline
\end{tabular}


These finding were in agreement with those of following investigators Helmy (2000) and Moustafa (2012) who noticed that the peaks of activity were occurred in April, August and October.

\section{Total number of dead stages}

Data presented in Tables ( 1 and 2 ) the total number of dead stages showed three peaks during the first year there were in September, November February with counts of 157, 370 and 706 individuals, respectively.

While, during the second one the total number of dead stages recorded two peaks occurred in November (1306 individuals) and February (1931 individuals).

Generally, the total number of dead stages during the second year (20162017) was clearly higher than those recorded during the first year (2015-2016) with counts of 8281 and 3134 individuals, consecutively.

\section{Percentages of total mortality}

As shown from obtained data in Tables (1 and 2), the percentages of total mortality indicated four peaks during the first year. They occurred in August (43.30\%), November (42.53\%), February (47.90\%) and finely in April (43.98\%). On the other hand, during the second year the percentages of total mortality showed two peaks they took place in August and February with 25.81 and $76.48 \%$ mortalities, successively.

The mean percentage of total mortality during the second year (55.07\%) was more that that during the first one (38.97\%).

\section{Percentages of parasitism}

During the course of this work, one hymenopterous specie was recorded as parasitoid of $P$. ziziphi. There was Aphytis sp. (Aphelinidae). The seasonal abundance of the parasitoid was
represented as percentages of parasitism.

Data presented in Tables ( 1 and 2 ) showed that the percentages of parasitism occurred two peaks of parasitism during the first year (20152016) and one peak during the second year (2016-2016). The peaks took place in November (5.29 \%) and May (19.16 \%) during the first year and in November (20.07\%) during the second one. The mean percentages of parasitism were 9.09 and $18.97 \%$ during the first and second years, successively.

This finding were in agreement with those of Rosen (1986) who recorded parasitic hymenopterous species mainly Aphytis spp. have proved to be quite useful for controlling diaspidids population. Kamel et al. (2003) reported that the parasitism rates of Aphytis species, were between 0.8 and $14.6 \%$. Darwish (2016) who revealed Aphytis lingnanensis and Encarsia citrine (Aphelinidae), were recorded as parasitoids of $P$. ziziphi. The mean of parasitism rate reach to $12.69 \%$ and $14.8 \%$ for $A$. lingnanensis in 2014 and 2015 years, respectively.

\section{Effect of climatic factors \\ On females}

Data in Tables ( $3 \& 4)$ showed that during the first year (2015-2016) temperature and solar radiation showed negative highly significant effects on females population whereas $r=-0.908^{* *}$ and $-0.723^{\star *}$. While, during the second year (2016-2017) relative humidity and solar radiation showed positive significant and negative highly significant effects where $r=0.677^{*}$ and 0.845**. Explained variance (E.V.\%) affected this stage by 88.13 and $89.21 \%$ during the first and second years. 
Table (3): Correlation coefficient (r) and explained variance (E.V.\%) represent the effects of climatic factors on Parlatoria ziziphi stages and its associated parasitoid on navel orange trees, in Shebin El-Kom, Menoufia Governorate during the first year (2015-2016)

\begin{tabular}{|l|c|c|c|c|cc||}
\hline $\begin{array}{c}\text { Parlatoria } \\
\text { ziziphi } \\
\text { stages }\end{array}$ & $\begin{array}{c}\text { Temp. } \\
\left({ }^{\circ} \mathrm{C}\right)\end{array}$ & $\begin{array}{c}\mathrm{RH} \\
(\%)\end{array}$ & $\begin{array}{c}\text { Solar } \\
\text { radiation } \\
\left(\mathrm{MJ} / \mathrm{m}^{2}\right)\end{array}$ & $\begin{array}{c}\text { Explained } \\
\text { variance } \\
(\mathrm{E} . \mathrm{V} . \%)\end{array}$ & \multicolumn{2}{|c|}{$\begin{array}{c}\text { Combined effect } \\
\mathrm{RH}\end{array}$} \\
\hline Females & $-0.908^{* *}$ & 0.507 & $-0.723^{* *}$ & 88.13 & Temp. ${ }^{\circ} \mathrm{C} \quad-0.634^{*}$ & $0.718^{* *}$ \\
\hline Males & $-0.848^{* *}$ & 0.392 & $-0.631^{*}$ & 80.02 & $\mathrm{RH}(\%)$ & $-0.815^{* *}$ \\
\hline Nymphs & $-0.611^{*}$ & 0.384 & -0.337 & 41.03 & & \\
\hline alive stages & $-0.924^{* *}$ & 0.515 & $-0.713^{* *}$ & 89.47 & & \\
\hline Mortality \% & -0.061 & -0.162 & -0.153 & 26.82 & & \\
\hline Parasitism \% & -0.057 & $-0.646^{*}$ & 0.503 & 84.68 & & \\
\hline \hline
\end{tabular}

Table (4): Correlation coefficient (r) and explained variance (E.V.\%) represent the effects of climatic factors on Parlatoria ziziphi stages and its associated parasitoid on navel orange trees, in Shebin El-Kom, Menoufia Governorate during the second year (2016-2017)

\begin{tabular}{|c|c|c|c|c|c|c|}
\hline $\begin{array}{l}\text { Parlatoria } \\
\text { ziziphi } \\
\text { stages }\end{array}$ & $\begin{array}{c}\text { Temp. } \\
\left({ }^{\circ} \mathrm{C}\right)\end{array}$ & $\begin{array}{l}\text { RH } \\
\text { (\%) }\end{array}$ & $\begin{array}{c}\text { Solar } \\
\text { radiation } \\
\left(\mathrm{MJ} / \mathrm{m}^{2}\right)\end{array}$ & $\begin{array}{l}\text { Explained } \\
\text { variance } \\
\text { (E.V. \%) }\end{array}$ & \begin{tabular}{l}
\multicolumn{2}{l}{ Combined e } \\
RH \\
Rola \\
$(\%)$
\end{tabular} & $\begin{array}{l}\text { fect } \\
\text { radiation } \\
\left(/ \mathrm{m}^{2}\right)\end{array}$ \\
\hline Females & -0.317 & $0.677^{*}$ & $-0.845^{\star *}$ & 89.21 & Temp. ${ }^{\circ} \mathrm{C}-0.662^{*}$ & $0.722^{\star *}$ \\
\hline Males & -0.310 & $0.788^{* *}$ & $-0.822^{* *}$ & 90.17 & RH (\%) & $-0.839 * *$ \\
\hline Nymphs & -0.222 & 0.234 & -0.406 & 72.31 & & \\
\hline alive stages & -0.191 & $0.595^{*}$ & $-0.763^{* *}$ & 85.30 & & \\
\hline mortality \% & $-0.731^{* *}$ & 0.202 & -0.365 & 67.72 & & \\
\hline Parasitism \% & -0.343 & -0.247 & -0.060 & 57.04 & & \\
\hline
\end{tabular}

\section{On males}

Data presented in Tables (3 and 4) showed that during the first year (20152016) temperature and solar radiation showed negative highly significant and negative significant effects on males population whereas $r=-0.848^{* *}$ and $0.631^{\star *}$, respectively. On the other hand, during the second year (2016-2017) relative humidity and solar radiation showed positive highly significant and negative highly significant effects where $r=0.788^{\star *}$ and $-0.822^{\star *}$, consecutively. Explained variance (E.v.\%) affected this stage by 80.02 and $90.17 \%$ during the first and second years, successively. 


\section{On nymphs}

Data given in Tables (3 and 4) showed that during the first year, there was a negative significant effect between nymphs population and temperature whereas $r=-0.611^{*}$. E.v.\% affected nymphs population by 41.08 and $72.31 \%$ during the first and second years.

\section{On total number of alive stages}

Data presented in Tables (3 and 4) showed that during the first year (20152016), there were a negative highly significant effect between the total number of alive stages and temperature and solar radiation whereas $r=-0.924^{\star *}$ and $-0.713^{* *}$. While, during the second year (2016-2017) relative humidity and solar radiation showed positive significant and negative highly significant effects on the total number of alive stages whereas $r=0.595^{*}$ and $0.763^{* *}$, respectively. E.v.\% affected this stage by 89.47 and $85.30 \%$ during the first and second years.

\section{On percentages of total mortality}

Data given in Tables (3 and 4) cleared during the first year no significant effects were recorded on this stage. While, during the first year temperature had negative highly significant effect on the percentage of total mortality whereas $r=$ $-0.731^{* *}$.

Statistical analysis showed that E.v.\% affected percentages of total mortality by 26.82 and $67.72 \%$ during the first and second years.

\section{On percentages of parasitism}

As shown from obtained data in Tables (3 and 4) during the first year, temperature showed negative significant effects whereas $r=-0.646^{*}$. Statistical analysis showed that E.V.\% affected parasitism percentage by 84.68 and $57.04 \%$ during the two successive years.

\section{Combined effect of climatic factors}

Data given in Tables (3 and 4) indicated that there were negative significant effects between temperature and relative humidity whereas $(r)$ values were $-0.634^{*}$ and $-0.662^{*}$ during the first and second years, respectively. Also, temperature showed positive highly significant effects with solar radiation whereas ( $r$ ) values were $0.718^{\star *}$ and $0.722^{\star *}$ during the first and second years, respectively. During the first and second years relative humidity showed negative highly significant effects with solar radiation where $r=-0.815^{\star *}$ and $-0.839^{\star *}$, consecutively. Generally, it was clear that temperature and solar radiation had positive significant effects in all cases.

This finding was in agreement with those of (Nabil and Shahein 2014) who mentioned that there was a strong correlation between temperature and both insect population of, Aonidiella aurantii (Maskell) and its parasitoids. They added that the light intensity effects appeared significant in peripheral zone only on percentage of parasitism.

\section{Number of generations}

As $P$. ziziphi is known to have overlapping generations, it was necessary to utilize the formula of Audemard and Milaire (1975) and emended by Jacob (1977) for estimating the number of generations and durations.

As shown from the obtained data in Table (5) and Fig. (1), during the first year (2015-2016) P. ziziphi had two annual generations on navel orange. The first generation took about 6 months was during the beginning of June till the end of November. While, the second generation beginning from December till the end of May. On the other hand, during the second year (2016-2016) P. ziziphi had three generations the first generation took about three months was during from the beginning of June till the end of 
August. While, the second generation lasted about four months, from September till the end of December. The third generation occupied five months from the beginning of January till the end of May.
These results were in accordance with those of Helmy (2000) who reported that $P$. ziziphi had three generations a year on four citrus varieties (i.e. mandarin, baladi orange, grape fruit, and trifoliate orange trees).

Table (5): Annual generations and durations of Parlatoria ziziphi (Lucas) on navel orange trees, in Shebin El-Kom distract, Menoufia Governorate during the two successive years

\begin{tabular}{|c|c|c|c|c|}
\hline \multirow[b]{2}{*}{ Months } & \multicolumn{4}{|c|}{ Number of insects / 200 leaves } \\
\hline & $\begin{array}{c}\text { Accumulated } \\
\text { days of } \\
\text { investigation }\end{array}$ & $\begin{array}{l}\text { Monthly } \\
\text { counts of } \\
\text { nymphs }\end{array}$ & $\begin{array}{l}\text { Accumulated } \\
\text { monthly counts }\end{array}$ & $\begin{array}{c}\text { Accumulated } \\
\text { insects } \\
\%\end{array}$ \\
\hline \multicolumn{5}{|c|}{ first year (2015-2016) } \\
\hline Jun. & 30 & 10 & 10 & 2.27 \\
\hline Jul. & 61 & 16 & 26 & 5.90 \\
\hline Aug. & 92 & 9 & 35 & 7.94 \\
\hline Sep. & 122 & 10 & 45 & 10.20 \\
\hline Oct. & 153 & 15 & 60 & 13.61 \\
\hline Nov. & 183 & 14 & 74 & 16.78 \\
\hline Dec. & 214 & 156 & 230 & 52.15 \\
\hline Jan. 2016 & 245 & 23 & 253 & 57.37 \\
\hline Feb. & 274 & 56 & 309 & 70.07 \\
\hline Mar. & 305 & 38 & 347 & 78.68 \\
\hline Apr. & 335 & 52 & 399 & 90.48 \\
\hline May & 366 & 42 & 441 & 100.00 \\
\hline \multicolumn{5}{|c|}{ first year (2016-2017) } \\
\hline Jun. & 30 & 14 & 14 & 1.38 \\
\hline Jul. & 61 & 30 & 44 & 4.33 \\
\hline Aug. & 92 & 66 & 110 & 10.84 \\
\hline Sep. & 122 & 361 & 471 & 46.40 \\
\hline Oct. & 153 & 226 & 697 & 68.67 \\
\hline Nov. & 183 & 176 & 873 & 86.01 \\
\hline Dec. & 214 & 55 & 928 & 91.43 \\
\hline Jan. 2017 & 245 & 27 & 955 & 94.09 \\
\hline Feb. & 273 & 33 & 988 & 97.34 \\
\hline Mar. & 304 & 14 & 1002 & 98.72 \\
\hline Apr. & 334 & 7 & 1009 & 99.41 \\
\hline May & 365 & 6 & 1015 & 100.00 \\
\hline
\end{tabular}



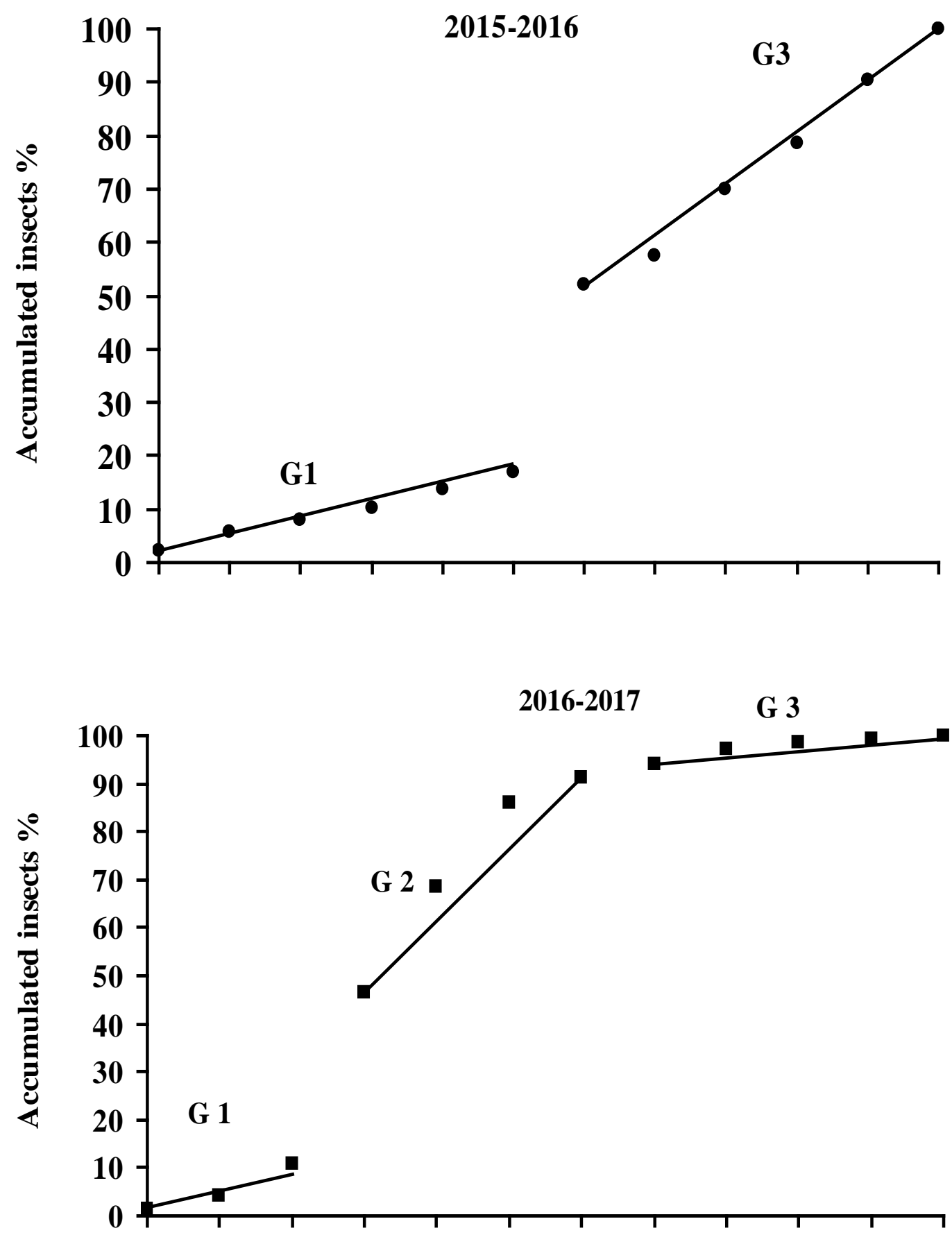

Jun. Jul. Aug. Sep. Oct. Nov. Dec. Jan. Feb. Mar. Apr. May Months

Fig. (1): Annual generations and their durations of Parlatoria ziziphi (Lucas) on navel orange trees, in Shebin El-Kom district, Menoufia Governorate during the two successive years. 
Hassan et al. (2012) who mentioned that the scale had 2 to 3 generations I year there were begin in June to October and the second started in April to May.

\section{REFERENCES}

Audemard, H. and H.G. Milaire (1975). Le pieeage carpocapse (Laspeyresia pomonella L.) avec une pheromone sexuelle de synthese: premiers resultats utilisables pour 1 estimation des populations et laconduite de la lutte. Ann. Zoll. Ecol. Anim.: 7- 61.

Capinera, J.L. (2008). Encyclopedia of Entomology "Citrus pests and their Management". 2nd Edition, Springer Science + Business Media B.V., Dept. of Entomology and Nematology, Univ. of Florida, USA, pp. 896.

COSTAT (2005). Version 6.311, Copyright(c), CoHort Software, 798 Lighthouse Ave. PMB 320, Monterey, CA, 93940, USA.

Darwish, A.A.E. (2016). Some ecological and behavioral aspects of the black parlatoria, Parlatoria ziziphi (Lucas) (Hemiptera: Diaspididae) and its parasites on mandarin trees. International Journal of Entomology Research, 1(4): 33-38.

Franco, J.C., A. Zada and Z. Mendel (2009). Novel approaches for the management of mealybug pests. In: Ishaaya I., Horowitz A.R. (eds): Biorational Control of Arthropod Pests-Application and Resistance Management. Dordrecht, Springer: 233-278.

Germain, G.F. (2008). Invasive scale insects (Hemiptera: Coccoidea) recorded from France. In: Branco M., Franco J.C., Hodgson C. (eds): Proceeding XI International Symposium on Scale Insect Studies, Sept 24-27, 2007, Oeiras, Portugal. Lisbon, ISA Press: 77-87.
Zaabta (2016) who recorded that the scale had three generations per year the first in fall, the second in spring and the third during summer.

Hassan, N.A., S.G. Radwan and O.M.N. ElSahn (2012). Common scale insects (Hemiptera:Coccoidea) in Egypt. Egypt. Acad. J. Biolog. Sci., 5(3): 153 160.

Helmy, S.M.Y. (2000). Ecological studies on the black parlatoria scale, Parlatoria ziziphus (Lucas) (Homoptera: Diaspididae) and its natural enemies in Egypt. M.Sc. Thesis, Fac. Agric., Cairo Univ., Egypt.

Jacob, N. (1977). Un model matematic pentru stabilirea. Limitelor economice de toloranta a atacului molilor. Fructelor in lupte integrate. Analele I. C. P. P., Romania, 15: 179.

Kamel, A., S. Abd-Rabou, N. Hilmy, S. Allam and M. Moustafa (2003). Seasonal abundance of certain Aphytis species (Hymenoptera: Aphelinidae) from Egypt. Egyptian Journal of Agriculture Research, 81 (3): 1009-1023.

Kondo, T., P.J. Gullan and D.J. Williams (2008). Coccidology: The study of scale insects (Hemiptera: Sternorrhyncha: Coccoidea). Revista Corpoica - Ciencia y Tecnología Agropecuaria, 9: 55-61.

Mazzeo, G., S. Longo, G. Pellizzari, F. Porcelli, P. Suma and A. Russo (2014). Exotic scale insects (Coccoidea) on ornamental plants in Italy: a neverending story. Acta Zoologica Bulgarica, 6: 55-61.

Miller, D.R. (2005). Selected scale insect groups (Hemiptera: Coccoidea) in the southern region of the United States. Florida Entomologist, 88: 482-501.

Miller, D.R., G.L. Miller and G.W. Watson (2002). Invasive species of mealybugs (Hemiptera: Pseudococcidae) and their threat to U.S. agriculture. 
Proceeding of the Entomological Society of Washington, 104: 825-836.

Moustafa, M. (2012). Scale insects (Coccoidae: Hemiptera) infested citrus trees and their natural enemies, with a key of these pests in Egypt. Egypt. Acad. J. biolog. Sci., 5(1): 1- 23.

Nabil, H.A. and A.A. Shahein (2014). Ecological studies on Aonidiella aurantii (Maskell) infesting navel orange trees and its associated parasitoid, Aphytis lingnanensis Compere in Ismailia Governorate, Egypt. Zagazig J. Agric. Res., 41(6): 1293-1300.

Pellizzari, G. and G.F. Germainm (2010). Scales (Hemiptera, Superfamily Coccoidea). Bio Risk, 4: 475-510.

Rosen, D. (1986). Natural enemies of Diaspididae and their utilization in biological control. $5^{\text {th }}$ Int. Symp. on
Scale Insect Studies Portici, Italy: 2428.

Ross, L., I. Pen and D.M. Shuker (2010): Genomic conflict in scale insects: the causes and consequences of bizarre genetic systems. Biological Reviews, 85: 807-828.

Tawfeek, M.E. and Amany M.H. Abu-Shall (2010). Seasonal population dynamics of Parlatoria ziziphus (Lucas) (Homoptera: Diaspididae) in Menoufia Governorate, Egypt. Alexandria Science Exchange Journal, 31(4): 331338.

Zaabta, I. (2016). Ecologie de deux bioagresseurs des agrumes Lepidosaphes beckii et Parlatoria ziziphi (Homoptera : Diaspididae) dans un verger d'oranger à Rouiba. M.Sc. thesis, Ecole Nationale Superieure Agronomiqye, El-Harrach, Algérie. (in French). 
Parlatoria ziziphi (Lucas) راسات إيكولوجية على حشرة البرلاتوريا السوداء التى تصيب أثجار البرتقال أبوسرة بمحافظة المنوفية - مصر

حسن أحمد نبيل(")، باسم محمد الدفراوى(ץ)، أحمد أحمد عبد الحميد الدش(؟)،

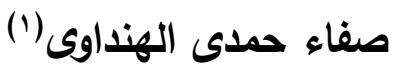

$$
\text { (1) معهل بحوث وقاية النباتات - مركز البحوث الزراعية }
$$


الملخص العربى

أُجريت هذه الدراسة بمزرعة كلية الزراعة بثبين الكوم بمحافظة المنوفية مصر على حشرة البرلاتوريا السوداء

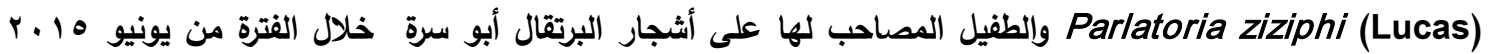

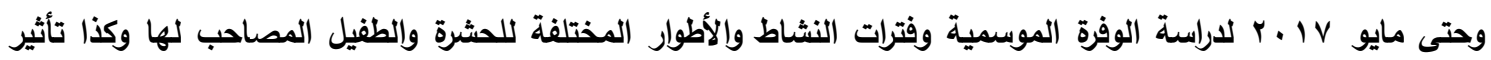



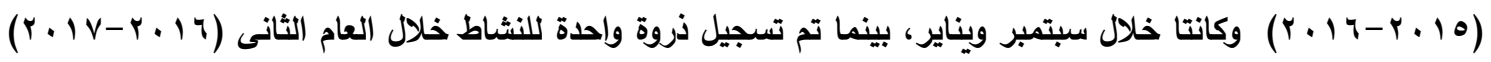

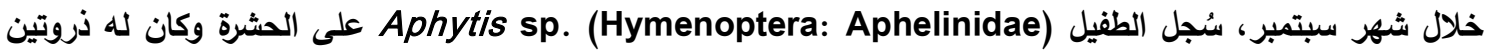

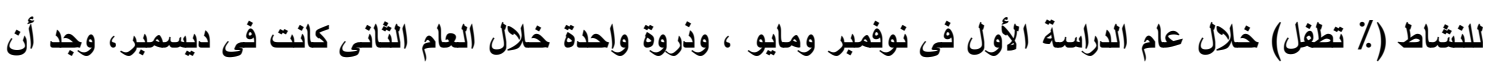

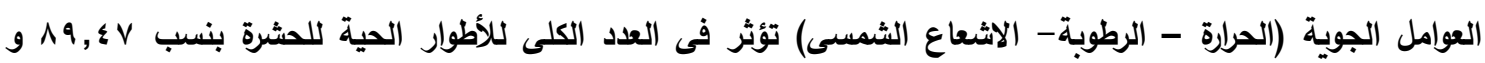

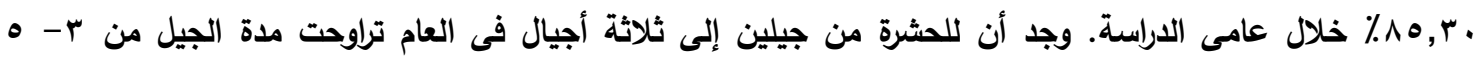
شهور. 
H.A. Nabil, et al., 